\title{
HEDGE FUNDS AS LIQUIDITY PROVIDERS: EVIDENCE FROM THE LEHMAN BANKRUPTCY
}

\author{
George O. Aragon \\ Philip E. Strahan \\ Working Paper 15336 \\ http://www.nber.org/papers/w15336
NATIONAL BUREAU OF ECONOMIC RESEARCH 1050 Massachusetts Avenue
Cambridge, MA 02138
September 2009

The views expressed herein are those of the author(s) and do not necessarily reflect the views of the National Bureau of Economic Research.

NBER working papers are circulated for discussion and comment purposes. They have not been peerreviewed or been subject to the review by the NBER Board of Directors that accompanies official NBER publications.

(C) 2009 by George O. Aragon and Philip E. Strahan. All rights reserved. Short sections of text, not to exceed two paragraphs, may be quoted without explicit permission provided that full credit, including (c) notice, is given to the source. 
Hedge Funds as Liquidity Providers: Evidence from the Lehman Bankruptcy

George O. Aragon and Philip E. Strahan

NBER Working Paper No. 15336

September 2009

JEL No. G12,G2,G21

\begin{abstract}
$\underline{\text { ABSTRACT }}$
Using the September 15, 2008 bankruptcy of Lehman Brothers as an exogenous shock to funding costs, we show that hedge funds act as liquidity providers. Hedge funds using Lehman as prime broker could not trade after the bankruptcy, and these funds failed twice as often as otherwise-similar funds after September 15 (but not before). Stocks traded by the Lehman-connected hedge funds in turn experienced greater declines in market liquidity following the bankruptcy than other stocks; and, the effect was larger for ex ante illiquid stocks. We conclude that shocks to traders' funding liquidity reduce the market liquidity of the assets that they trade.
\end{abstract}

George O. Aragon

Arizona State University

Tempe, AZ

George.Aragon@asu.edu

Philip E. Strahan

Carroll School of Management

324B Fulton Hall

Boston College

Chestnut Hill, MA 02467

and NBER

philip.strahan@bc.edu 


\section{INTRODUCTION}

Hedge funds differ from mutual funds because their trading strategies and their contractual relationships with investors are unfettered by regulation. Without regulatory constraint, hedge funds can invest more patiently than mutual funds by imposing tight lockups and redemption restrictions on their investors. These advantages may allow hedge funds to earn higher returns because they can hold illiquid positions (Aragon, 2007). They may also earn higher returns on information production than mutual funds because they may take short positions, they may use derivatives extensively, and they may leverage their long positions with debt (Aragon and Martin, 2009).

Hedge funds have grown in importance, with total assets rising from $\$ 38$ billion in 1990 to $\$ 1.9$ trillion by the end of 2007 (Lo, 2008). How has this explosive growth affected market liquidity and the dynamics of asset prices? This question is difficult to answer because hedge funds enter markets where profit opportunities are likely to be greatest. Thus, they may be more likely to trade in relatively illiquid markets, where temporary deviations of prices from fundamentals are larger and more persistent, and they may enter and exit trades as liquidity and pricing dynamics shift. Long-Term Capital Management (LTCM), for example, famously traded on strategies related to changes in liquidity, such as those that occur in the U.S. Treasury market, where yields predictably rise as bonds move from the 'on-the-run' classification (where they trade actively) to the 'off-the-run' classification (where they tend to be purchased by buy-andhold investors).

This paper tests how hedge-fund trading affects market liquidity. We sidestep the endogeneity of their trading strategies by exploiting a 'natural' experiment, the Lehman 
Brothers bankruptcy, which constituted a plausibly exogenous shock to some hedge funds' ability to trade their positions. Lehman Brothers acted as one of the major prime brokers prior to its bankruptcy on September 15, 2008. Prime brokers provide custodial services, securities lending services, and financing to their hedge fund customers. Lehman could no longer provide these services after they failed, primarily as a result of their exposure to real estate. The accounts of many of their hedge fund clients were frozen, making it impossible for them to trade or to switch to a competing broker. As we document, the failure rate of Lehman's hedge-fund clients doubled after the bankruptcy, relative to funds with similar performance characteristics using other brokers. Lehman's demise hampered the ability of some hedge funds to trade their positions, leading to an increase in their failure rate.

Next we show that stocks held by Lehman's hedge-fund clients prior to the bankruptcy experienced unexpectedly large declines in liquidity after the bankruptcy, compared to otherwise similar stocks not held by hedge funds exposed to Lehman Brothers. The overall price impact of trades on these stocks rose (i.e. the Amihud illiquidity index, equal to the ratio of absolute returns to dollar volume), as did their bidask spreads. Liquidity overall dropped sharply for all stocks; our cross-sectional result implies that stocks held by Lehman-connected hedge funds experienced larger declines in liquidity than other stocks. We also find that the effect of Lehman-fund holdings is greatest among the relatively less liquid assets (based on pre-crisis liquidity measures). Conversely, we find that stocks with greater ownership by other institutional investors and by non-Lehman hedge funds experienced significantly smaller declines in liquidity than other stocks. Institutional investors thus seemed to have supplied liquidity - or at 
least reduced the increase in demand for liquidity - during the post-Lehman stock market collapse. Lehman Brothers' hedge-fund customers were unable to fulfill this stabilizing role because they were constrained in their ability to trade their positions.

Figures 1 and 2 illustrate our key result graphically. We report the average percentage change in Amihud's illiquidity index from the three months before to the three months after Lehman's bankruptcy. The index increased across the whole stock market as liquidity dried up across the board. Said slightly differently, stock-return volatility increased much more than trading volume due to greater price impact of trades in the less liquid environment that prevailed after September. But, as the figure shows, the decline in liquidity was larger for stocks held by hedge funds that used Lehman as their prime broker (Figure 1). For stocks with illiquidity above the median during the pre-crisis months, the increase was much more pronounced (Figure 2). For example, illiquid stocks not held by Lehman-connected funds experienced an increase in illiquidity of about $95 \%$, compared to an increase of almost $140 \%$ for stocks with more than $5 \%$ of their shares owned by these funds.

We then decompose total price-impact into its permanent and transitory components, as in Glosten and Harris (1988), Brennan and Subrahmanian (1996), Chordia et al. (2001), and Sadka (2006). The permanent component of price impact reflects costs faced by uninformed market makers when they trade against better informed investors. Intuitively, prices increase permanently in response to buy-side volume to reflect the probability that a given buy order implies private information about fundamentals. Vice versa for sell orders. The temporary component - that part of price 
impact related to short-term shocks to volume - reflects inventory holding costs to market makers.

We find opposing results when we disentangle the overall price-impact. The permanent component falls for stocks held by Lehman's hedge fund clients, while the temporary component rises. The result suggests that hedge fund trading increases liquidity relative to short-term shocks to volume, presumably because they trade patiently and are able to absorb some of the variation in liquidity demands from high-frequency 'noise trades'. ${ }^{1}$ Hedge funds also invest in private information themselves, however, meaning that some of their trades impose adverse selection costs on other less-informed liquidity suppliers (market makers). Thus, the permanent component of price impact decreases for stocks held by Lehman's hedge fund clients, suggesting that information content in trades falls.

The results suggests that the long-term growth of hedge-fund trading has had mixed effects on overall liquidity - increasing short-term liquidity but raising the adverse selection costs to market makers. The results are consistent with hedge funds earning high returns both because they supply liquidity to noise traders and because they invest in private information.

The results also provide support for models of liquidity spillovers such as Brunnermeier and Pedersen (2007), whose model links the funding liquidity of traders to the market liquidity of the assets that they trade. Finding a causal link from funding to market liquidity is difficult empirically because there is a two-way feedback between them. In our case, however, traders linked to Lehman Brothers faced an exogenous

\footnotetext{
${ }^{1}$ Agarwal et al. (2007) and Getmansky et al. (2009) empirically study hedge funds' role in providing liquidity to the convertible bond market."
} 
negative shock to their funding liquidity because their prime broker failed. Brunnermeier and Pedersen emphasize the problem of downward liquidity spirals, whereby declines in prices in one market can spill over into other markets because traders' ability to borrow becomes constrained as their wealth declines. Our result is a direct and clean verification of this idea. We show, first, that the hedge funds connected to Lehman suffer, and, second, that this in turn spills over into the market in which those connected funds trade.

The remainder of our paper is organized into two main sections and a brief conclusion. Section II describes the role of the prime broker for hedge funds. We report simple comparisons of funds connected and not connected to Lehman, and then estimate a hazard model of fund survival as a function of affiliation with Lehman, controlling for performance measures. In section III, we compare changes in four market liquidity measures of U.S. stocks as a function of the amount of pre-crisis ownership in those stocks by the Lehman-affiliated funds. These multivariate tests support the inferences that one would draw from the simple analysis of changes in liquidity illustrated in Figures 1 and 2. Section IV concludes.

\section{LEHMAN BROTHERS BANKRUPTCY AND ITS HEDGE-FUND CLIENTS}

Lehman Brothers had become one of the major prime brokers for hedge funds

during the years leading up to its failure in 2008. Prime brokers provide their hedge-fund customers with cash management services, securities lending services, and financing services, among other things. The business of prime brokerage grew rapidly over the past 10 years as assets under management at hedge funds took off. As has been well recognized, brokers bear substantial counterparty risk relative to their hedge-fund clients. 
Prime brokers routinely lend to hedge funds to support their long positions, holding those long positions as collateral. Rapid declines in collateral value can potentially expose the broker to losses, as famously occurred on a massive scale in the blow-up of LTCM in 1998.

What has been less well understood until recently, however, is that hedge funds are in turn exposed to the failure of their prime broker. For example, prime brokers sometimes lend securities purchased by hedge funds to other investors in a process known as re-hypothecation. Re-hypothecation generates fees for the prime broker, but it also creates counterparty risk for the hedge fund by making it difficult for the fund to reclaim its securities if the broker fails. As one hedge fund manager commented in the wake of Lehman's failure, "If you gave your assets to Lehman as collateral and they lent those out, then more than one person has a claim on those assets. Everyone passes around the security, then the music stops, there is one chair to sit on and too many people who want to sit on it (Euromoney, November 2008)."

The Oak Group was a medium-sized hedge fund that used Lehman Brothers International, based in London, as its prime broker. ${ }^{2}$ Oak Group's demise illustrates how the Lehman bankruptcy affected its hedge-fund customers. Oak group had \$22 million in long positions matched with $\$ 22$ million in short positions, plus $\$ 16$ million in cash in a margin account. All of these positions were held by Lehman, who had lent out the $\$ 22$ million in Oak Group's long positions (an example of re-hypothecation). Thus when

\footnotetext{
${ }^{2}$ U.S. securities law requires that prime brokers disclose this practice and receive written permission from customers, but no such law exists in London, where much of the hedge fund business has moved. In fact, Lehman's main prime brokerage business was run out of London in its subsidiary, Lehman Brothers International (Aiken and Singh, 2009). The lighter regulation of prime brokers in the UK allowed them to extend credit on more favorable terms to their clients, but also likely increased the counterparty risk to hedge funds and other investors.
} 
Lehman failed, Oak Group could not regain its securities or its cash; they became a general creditor of Lehman Brothers. As John James, the head of Oak Group, said, "Without those securities, my strategy has been ruined. Had we had the securities and been able to continue trading, we would have been up about $6 \%$ over the last six weeks." Liu and Mello (2009) show theoretically that even the suspicion of a funding shock can lead to a hedge fund's demise.

Overall Lehman had lent out in aggregate $\$ 22$ billion in securities when it entered bankruptcy (Euromoney, 2008). If many of its clients could not trade, the market liquidity of positions held by those clients could reasonably be expected to decline. In fact, this is precisely what is predicted in Brunnermeier and Pedersen (2007). However, linking the failure of Lehman to the level of asset prices is less clear. If liquidity is a priced risk factor, then shocks to market liquidity could lower asset prices, and raise expected returns going forward (e.g. Amihud and Mendelson ,1986; Pastor and Stambaugh, 2003; Acharya and Pedersen, 2005). But in the Lehman case there is anecdotal evidence that some hedge funds faced a short squeeze because securities lenders exposed to Lehman recalled their loans, forcing those borrowers to repurchase shares and putting upward pressure on prices (Bloomberg, 2008). ${ }^{3}$

\section{Measuring Lehman-Exposed Hedge Funds and their Holdings}

To implement our empirical tests, we first want to identify those hedge funds that continued to use Lehman as their prime broker when Lehman entered bankruptcy in September of 2008. Second, we want to identify the positions held by those hedge funds. Together these data will allow us to test for spillovers from the bankruptcy to those assets. We are able to build proxies for both of these steps from available data. The

\footnotetext{
${ }^{3}$ See http://www.bloomberg.com/apps/news?pid=20601213\&refer=home\&sid=ad09Cf8uGNn0.
} 
proxies are imperfect, but this problem will tend to attenuate rather than amplify our results.

Our main source for hedge fund data is TASS, which includes a history of hedge fund returns as well as a series of characteristics. TASS updates its data on a daily basis, with changes from one version to the next reflecting the addition of new funds reporting to the database, updated performance data of existing funds, and movements of a fund from the live folder (i.e., funds that are still reporting) to the graveyard folder (i.e., funds that have ceased reporting). The most recent version of the database is available for daily download from the website, but prior versions are not currently available. We have downloads of the database in 2002 (January and September), 2003 (January), 2005 (December), and 2006 (April), and we have multiple snapshots in 2007, 2008 and 2009. In all we have 102 snapshots of the TASS data. Most important, we have a snapshot of TASS in August 2008, just prior to Lehman's bankruptcy.

TASS contains information on the prime broker, along with other affiliated companies (e.g., Bank, Custodian, Administrator, Management Firm, Auditor, Legal), in the "Companies.txt" file. Since funds sometimes change their use of brokers, we use all available versions of the database to construct a panel of fund affiliations with their prime broker. Affiliated prime brokers are identified when the string observation in the "Company Type" field equals "Prime Broker." We identify 1,556 unique non-missing entries in the "CompanyName" field for the prime broker company type. We clean the reported names of the fund affiliates because the same broker might be coded differently by two different funds. We also need to account for the fact that some funds report 
multiple prime brokers in the "Company Name" field. After hand checking the raw list, we end with a final master list containing 381 unique prime brokers.

Table 1 reports the names and average market shares of the top 10 prime brokers over time. Market share is computed across all available versions of the database and averaged across each year; we define market share as the ratio of the number of a prime broker's affiliated funds divided by total funds reporting a non-missing prime broker affiliation. As we have argued above, and as we will show empirically below, the Lehman bankruptcy led to unexpectedly high failure rates for its hedge fund customers (controlling for performance). In fact, hedge funds have recently become more concerned about counterparty risk. Since the fall of 2008, for example, an increasingly large number of funds have begun spreading their business across multiple brokers, leading to a decline in prime brokerage market concentration. The share of the top three brokers held steady at about $50 \%$ until 2007 , then fell to $41 \%$ by 2009 . And, eight of the top ten brokers lost market share between 2008 and 2009. The two exceptions - Deutsche Bank and Credit Suisse First Boston - both experienced a slight increase in market share over this period.

Table 2 reports summary statistics for the prime broker affiliations for the sample of hedge funds. The first row reports the number of unique fund-year observations. For example, across the six years of available versions of the database, there are 25,728 unique fund-year observations. The rise in the number of observations from $2002(2,219)$ to $2008(8,560)$ reflects a growth in the number of funds. The second row reports the frequency with which prime broker affiliations are missing. The frequency of missing data varies over the sample, from $32 \%$ in 2002 to $61 \%$ in 2008 . The prime brokerage 
business is highly competitive, and hedge funds often will switch from one to a competitor. During our sample, for example, $25 \%$ of the funds changed their prime broker between 2003 and 2005. This dynamism highlights the importance of reconstructing a panel of prime brokerage affiliations using prior versions of the database. The third column shows that the proportion of funds reporting multiple prime brokerage affiliations is infrequent (about 1.1\%) for the full sample.

Table 3 summarizes various characteristics of funds that reported at least one return observation to TASS in 2008. Since our last download before September 15, 2008 was on August 2, 2008, we know that these classifications are very close to what actually occurred as Lehman entered bankruptcy. The table makes univariate comparisons, depending on whether the fund's reported prime brokerage affiliation is Lehman Brothers. Non-Lehman funds are those that report a prime brokerage affiliation other than Lehman Brothers (we drop funds that do not report a prime broker in TASS). The classification of each fund is determined using the fund's latest reported prime brokerage affiliation prior to September, 2008. Failure itself is not directly observable in TASS, so we use the frequency with which a fund's last reported return appears in 2008 as our proxy for fund liquidation (first row of Table 3). Since advertising is a primary reason for funds to report performance data to the database, some funds may drop out of TASS even if they have not failed. Getmansky, Lo, and Mei (2004), however, argue that over $90 \%$ of funds that stop reporting from the database are plausibly liquidated funds.

\section{Hazard model of hedge fund failure}

The raw data clearly suggest that Lehman's bankruptcy harmed its hedge-fund customers. For example, $45 \%$ of the 77 Lehman-affiliated funds appear to have been 
liquidated in 2008, compared to $32 \%$ for other funds (Table 3). The second and third rows of Table 3 show that Lehman funds had fewer monthly observations and lower returns in 2007. For example, Lehman funds returned $6 \%$ to investors in 2007, as compared to $12 \%$ for Non-Lehman funds. The average net assets and use of share restrictions (lockup and notice periods) of Lehman funds are significantly lower than Non-Lehman funds. ${ }^{4}$

To validate the differences in raw liquidation rates, we report a proportional hazard model of the time to hedge-fund failure as a function of style, performance, size, flow and prime brokerage affiliation. Our estimation is based on a panel of fund-year observations between 2002 and 2009. ${ }^{5}$ Although returns are available from 1994, the prime brokerage affiliation and fund characteristics are only available in cross-sectional "snapshots" of the 102 versions of the database that we have downloaded. Therefore, since we can not recover these affiliations before 2002, we start the sample in 2002 and update the information with each new version of the database. In the interim, between available versions of the database, we carry forward the prime brokerage and characteristics information from the most recently available version of the database. This approach has the appeal that our predictors are indeed in the information set when we classify surviving funds each year.

The time variable in our model for each fund equals the number of days since the date of the first return observation recorded in TASS. The time and failure variables

\footnotetext{
${ }^{4}$ We find similar results in our univariate (Table 3) and survival (Table 4) analyses when we expand the Lehman group to include the 151 funds that are affiliated with Lehman at the family-level.

${ }^{5}$ Although the analysis of stock-return liquidity below ends in 2008, we use data through June 2009 in order to account for late reporting of 2008 fund returns to TASS.
} 
yield the baseline hazard rate for our hedge fund sample. ${ }^{6}$ We also include several explanatory variables that plausibly shift the baseline hazard rate, such as the natural logarithm of total assets under management, returns from the current year, and annual net fund flows. All variables are measured at the end of each year or, if the fund fails within the year, at the fund failure date. We expect higher returns, greater flows and larger fund size all to lead to a decrease in the hazard rate, and this would be reflected in hazard ratios (coefficients) less than one. We also include the natural logarithm of the lockup and redemption notice periods as explanatory variables. Aragon (2007) argues that share restrictions on hedge funds reduce non-discretionary trading costs and improve fund profitability. Therefore, it seems plausible that share restrictions may be associated with a lower hazard rate.

To validate our identification strategy - that is, to show that hedge funds were harmed by Lehman's collapse - we include a 2008 calendar-year indicator, an indicator equal to one if the fund's prime brokerage affiliation was with Lehman Brothers, and their interaction. We are careful to measure the Lehman dummy using only the data prior to September, 2008. A finding that 2008 is associated with a greater hazard ratio would not be surprising in light of extraordinarily credit events during this period. Our main hypothesis is that 2008 was an especially difficult year for funds exposed to the Lehman Brothers' bankruptcy. The key variable of interest is thus the interaction between the year-2008 indicator and the indicator for Lehman affiliation. A coefficient greater than

\footnotetext{
${ }^{6}$ We assume that the Weibull distribution describes the baseline hazard rate. This distribution allows some flexibility in the baseline hazard rate, allowing it to increase, decrease or remain constant over time. Our results for the effects of the Lehman bankruptcy are similar if we estimate the model with the Cox proportional hazard model, which imposes no structure at all on the baseline hazard rate.
} 
one for this variable would suggest that the hazard rate increased more in 2008 for hedge funds affiliated with Lehman Brothers than for other funds. ${ }^{7}$

The results strongly suggest that Lehman brought many of its customers down when it failed in September (Table 4). The hazard analysis shows that hedge-fund failure rates increased across the board in 2008 - the year-2008 indicator enters with a coefficient of 1.5 or higher (depending on the model), meaning that failure rates increased by at least $50 \%$ in 2008 relative to the earlier years. Note that this increase goes beyond what one would predict based on performance, which was itself very poor during that year. The interaction between the Lehman indicator and the 2008 indicators exceeds two across all but one of the specifications. Thus, Lehman-affiliated hedge funds were twice as likely to fail in 2008 as otherwise similar firms in that year. Prior to 2008, however, there was no difference in failure rates for Lehman customers (i.e. the direct effect of the Lehman indicator is not statistically significantly different from one). ${ }^{8}$ The other characteristics enter the model as one would expect - larger funds, funds with greater net flow, and funds with better recent performance have lower hazard rates than others funds (i.e. the coefficients on these variables are significantly less than one). We find no effect of redemption restrictions or lockups on fund survival, however; this null result may reflect the endogeneity of these contract terms.

\footnotetext{
${ }^{7}$ Standard errors are clustered at the fund-level. Style dummies are included in the final model. All explanatory variables except the dummies are standardized to have zero mean and unit variance. We ignore assets under management that are not reported in US Dollars or Euros.

${ }^{8}$ We have also estimated a similar model that also includes a Bear Stearns indicator and its interaction with the 2008 dummy. This model suggests that the hazard rate also rose for Bear's customers in 2008, but by a much smaller magnitude - on the order of $40 \%$ compared to a more than doubling in the Lehman case. This difference likely occurred because Bear Stearns avoided bankruptcy so that its customers' accounts, and thus their ability to trade, did not suffer.
} 


\section{LIQUIDITY AFTER THE FALL OF LEHMAN}

\section{Estimation Strategy}

In this section we study whether the market liquidity of stocks held by Lehmanconnected hedge funds declines following the Lehman Brothers collapse, relative to similar stocks not held by these funds. We test for a spillover from declines in the funding liquidity of investors (Lehman-connected hedge funds) to declines in the market liquidity of assets that they hold. These tests amount to a series of cross-sectional regressions with the following general structure:

\section{Post-Crisis Illiquidity $_{i}=\alpha+\beta$ Pre-Crisis Illiquidity I $_{i}+\gamma$ Lehman-HF holdings $_{i}+$$$
\text { Pre-Crisis Control Variables }{ }_{i}+\varepsilon_{i}
$$

where $i$ is an index across stocks. Our key variable of interest, Lehman-HF holdings, equals the fraction of shares in stock $i$ that are held in aggregate by all hedge funds that used Lehman as their prime broker. If funding liquidity affects market liquidity, then $\gamma>$ 0. Since we measure these holding before the onset of the crisis, we can isolate the causality running from the funding shock to the market liquidity shock. Also, by controlling for the illiquidity measures during the pre-crisis period, we remove the firmspecific variation that is unrelated to the onset (or worsening) of the financial crisis in September. ${ }^{9}$ Since the crisis may have had differential effects across firms, however, we also control for pre-crisis firm size (log of market capitalization and the size rank) as well

\footnotetext{
${ }^{9}$ An alternative approach would be to explain the cross-section of changes in liquidity as a function of precrisis characteristics. This alternate strategy is similar to ours since it merely imposes a restriction that the coefficient $\beta=1$ to equation (1). We have estimated these models and find results similar to those reported below.
} 
as industry effects (at either the 2-digit or the 3-digit level of disaggregation). We also include the share of holdings by other non-Lehman hedge funds and the share of nonhedge fund institutional investors, which provide two additional benchmarks (beyond testing that $\gamma=0$ ) on how institutions overall affected liquidity.

Although hedge funds are generally not required to disclose their complete holdings to the public, Section 13(f) of the Securities Act of 1933 requires all investment advisers managing more than $\$ 100$ million to file their long positions in stocks on Form $13 \mathrm{~F}$ at the end of every quarter. We use these filings as of June 2008 to build our key explanatory variable (Lehman-HF holdings $\left.s_{i}\right) .{ }^{10}$ From TASS, we are able to identify 128 hedge funds that use Lehman Brothers as their prime broker in their final report to TASS prior to September, 2008. In addition to the 77 funds studied earlier (Table 3), we also consider funds that have ceased reporting to TASS before 2008. These 128 individual funds are owned and managed by 25 unique investment advisors. Among these, 17 have filed a Form $13 \mathrm{~F}$ with the SEC in the second quarter of 2008. We augment the TASS sample with eleven other hedge funds advisors that the popular press identifies as having a prime brokerage affiliation with Lehman Brothers at the time of bankruptcy. ${ }^{11} \mathrm{We}$ retrieve their stock holdings from the $13 \mathrm{~F}$ filings and compute, for each stock, the fraction of total shares outstanding owned by these Lehman-affiliated hedge funds. In

\footnotetext{
${ }^{10}$ In principle we would like to observe the identity of all stocks that these hedge funds might potentially trade, either long or short. We use actual long positions as the best available proxy for these stocks. Brunnermeier and Nagel (2004), Griffin and Xu (2009), and Aragon and Martin (2009) also study hedge fund holdings reported in Form 13F.

${ }^{11}$ See Cahill, T. (2008 October 1). Lehman Hedge-Fund Clients Left Cold as Assets Frozen. Bloomberg.com. http://www.bloomberg.com/apps/news?pid=20601087\&sid=adjHB.7sfLDA\&refer=home. See Thomas, L. (2008 October 1). Hedge Fund's Assets locked up in Lehman bankruptcy. The New York Times.
} 
aggregate, these 28 investment advisors held about $\$ 150$ billion in total stocks as of the middle of $2008 .^{12}$

\section{Liquidity measures}

For the dependent variable in Eq. 1, we study four distinct measures of illiquidity. The simplest two measures, constructed from CRSP daily data, equal the bid-ask spread divided by the mid-point of the spread (sometimes called the effective spread), and Amihud's illiquidity index (Amihud, 2002). The Amihud index equals the ratio of the absolute stock return to total dollar volume. The bid-ask spread measures the cost of making small trades. The Amihud index measures the average price impact for all trades made in equilibrium. A low level of this index suggests high liquidity because such stocks can absorb a lot of trading volume without large changes in prices; hence the index is negatively related to overall liquidity.

For each stock we compute these two measures on each day during the three months leading up to September 15, 2008 (the pre-crisis period) and the three months after September 15 (the post-crisis period). We then average these daily measures for each stock during the two regimes.

We also build two additional measures of liquidity to decompose the Amihud index into price impact related to adverse selection costs, and price impact related to order-processing costs. We follow existing studies (Glosten and Harris (1988), Brennan and Subrahmanyam (1996), and Sadka (2006)) and estimate these liquidity parameters from intraday data using the TAQ data. The literature distinguishes between permanent and transitory components of liquidity. The permanent component reflects changes in the market maker's valuation of the firm given the privately observed order flow. This is

\footnotetext{
${ }^{12}$ This figure reflects their holdings of stocks; total holdings of all assets would exceed this amount.
} 
commonly referred to as the "adverse selection costs" of trading. The transitory component reflects order-processing costs borne by the market-maker. These costs are transitory because they do not influence the market maker's private valuation of the security. Most of the permanent part of price impact comes from the variable component, whereas most of the temporary part comes from the fixed component. Thus we follow Sadka (2006) and focus only on the variable part of the permanent component and the fixed part of the temporary component.

To understand the decomposition, define $m(t)$ as the market maker's private valuation of the firm given the information contained in past and present order flow at time $t$. We assume:

$$
m(t)=m(t-1)+D(t) \times[\Psi+\lambda \times V(t)]+y(t)
$$

where $V(t)$ is the order flow, $D(t)$ is an indicator variable that equals one for a buyerinitiated order, and equals negative one for a seller-initiated order. Both $V(t)$ and $D(t)$ are private information observed only by the market maker. The variable $y(t)$ is the public information available at the end of day $t$. Equation (2) also shows that the adjustment to the market maker's valuation given order flow is assumed to contain both fixed $(\Psi)$ and variable $(\lambda)$ components.

We follow Sadka (2006) and assume that the market maker's private valuation depends only on the unpredictable variation in order flow. Specifically, in Eq. (2) we replace $D(t)$ and $D V(t)$ with the unexpected components of $D$ and $D V$, respectively. The unexpected part of signed order flow is defined as the residual to the model 


$$
D V(t)=\eta_{0}+\sum_{j=1}^{5} \eta_{j} \times D V(t-j)+\varepsilon_{\lambda}(t)
$$

We also assume that $\varepsilon_{\lambda}$ is normally distributed conditional on lagged observations of signed order flow. ${ }^{13}$ It is easy to show that this implies

$$
E_{t-1}[D(t)]=1-2 \times \Phi\left(-E_{t-1}\left[D V_{t}\right] / \sigma_{\varepsilon}\right)
$$

where $\sigma_{\varepsilon}$ denotes the square root of the conditional variance of $\varepsilon_{\lambda}$. The unexpected part of the buy/sell indicator is defined as $\varepsilon_{\Psi} \equiv D(t)-E_{t-1}[D(t)]$. We estimate Eq. (3) every month for each stock and use the fitted values for $E_{t-1}[D(t)]$. An estimate for $\sigma_{\varepsilon}$ is obtained as the square root of the sample mean squared error from the regression in Eq. (3).

The observed transaction price $(p(t))$ can then be written as,

$$
p(t)=m(t)+D(t) \times[\bar{\Psi}+\bar{\lambda} \times V(t)]
$$

The transaction price equals the market maker's private valuation plus the fixed and variable components of order-processing costs. This is the transitory component of liquidity. Taking first differences of Eq. (4) and substituting for $m(t)$ gives

$$
\Delta p(t)=\Psi \times \varepsilon_{\Psi}(t)+\lambda \times \varepsilon_{\lambda}(t)+\bar{\Psi} \times \Delta D(t)+\bar{\lambda} \times \Delta D V(t)+y(t),
$$

\footnotetext{
${ }^{13}$ Our results are similar if we use 10 lags in equation (3). Hence, the exact modeling of expected order flow has little impact on our conclusions.
} 
where $D V(t)=D(t) V(t)$ denotes the signed order flow. For each stock, we estimate the four liquidity parameters in Eq. (5) using OLS within each month. We require at least 30 trade observations for the estimation.

The TAQ files are divided into two files: a quotation file and a trade file. The quotation file classifies trades as either buyer or seller-initiated based on the Lee and Ready algorithm (1991). Specifically, we assume that prices exceed the midpoint of the bid and offer quotes for buyer-initiated trades, and that prices fall below the midpoint of the spread for seller-initiated trades. Trades that occur at the midpoint of the bid and offer are dropped. Lee and Ready (1991) argue that quotes less than 5 seconds old usually reflects information generated by the most recent trades. Therefore, when comparing trades and quotes, we compare the trade price with the most recent bid and offer quotes that have a timestamp of at least five seconds behind the timestamp of the trade.

We also apply the following filters to the trade data: First, we only consider NYSE-listed stocks, although we include trades that do not occur on the NYSE. Second, we keep only those trades that occur between the market opening (9:30 A.M. EST) and five minutes after the market closes (4:05 P.M. EST). Third, we keep only regular trades and original trades later corrected, and drop cancelled trades, trades out of sequence, and trades with special conditions. ${ }^{14}$ Fourth, we drop trades with negative prices and the first trade after the opening of the exchange. Fifth, we only keep primary market (NYSE)

\footnotetext{
${ }^{14}$ Specifically, we only keep trades if the TAQ correction indicator (Corr) equals 0 or 1 , and only if the sale condition field (Cond) is blank or equals “@” or "*””.
} 
quotes and quotes satisfying various criteria to assure the reasonableness of quote data. ${ }^{15}$ Finally, many trades and quotes have the same timestamp for a given security on a given day. In these cases, we only use the final reported trade and quote observation corresponding to each timestamp using the original sequence of observations provided by NYSE TAQ.

\section{Summary Statistics}

Table 5 reports summary statistics on the distribution for our liquidity measures in the pre-crisis and post-crises regimes. All of the measures suggest that liquidity fell quite sharply after the Lehman bankruptcy. The median effective spread rose from $0.3 \%$ to $0.8 \%$ for the full sample, and from $0.2 \%$ to $0.4 \%$ for New York Stock Exchange (NYSE) stocks. The Amihud measure also rose for both samples. The changes in liquidity are large and are consistent across the whole distribution, meaning that almost all stocks experience liquidity declines. Moreover, the separation of price-impact into its temporary and permanent components tells a similar story, although the magnitudes of the increases from the pre-crisis to the post-crisis period are smaller.

Before we continue, it is worth emphasizing that we are not attempting here to explain the shift in overall market liquidity. In our view it is difficult or impossible to disentangle the impact of the Lehman failure from the effects of the series of shocks that began around September 15, including the AIG rescue, the run on U.S. money market mutual funds, the widening of credit spreads, contagion into the UK and European banking systems, TARP, the extension of deposit insurance and guarantees of bank

\footnotetext{
${ }^{15}$ These criteria, used by Sadka (2006), are as follows: quotes in which the bid-ask spread is positive and below five dollars; quotes in which the bid-ask spread divided by the midpoint of the quoted bid and ask (aka the quoted spread) is less than $10 \%$ if the midpoint is greater than or equal to $\$ 50$; and quotes in which the quoted spread is less than $25 \%$ for midpoints less than $\$ 50$.
} 
liabilities, and the rapid and unprecedented creation of new lending facilities by the Federal Reserve. ${ }^{16}$ Since our empirical strategy focuses only on cross-sectional variation, the overall effects of these shocks will be absorbed by the intercept. To the extent that the effects of the crisis differed across firms, we absorb these differences with industry effects (and two measures of firm size).

Table 5 also reports the distribution of our measure of Lehman hedge-fund ownership and overall institutional ownership. We report these from just the pre-crisis period (June 2008) because our empirical strategy holds ownership fixed and asks how its impact on liquidity shifts after the Lehman bankruptcy (Eq. 1). Most of the stocks have very low levels of ownership by hedge funds connected to Lehman, but there are more than 650 stocks with ownership above $1.5 \%$ for these hedge funds, and more than 200 have ownership above 5\% (Table 5).

Results

We report the liquidity results in Tables 6-8. Table 6 contains the models of the bid-ask spread, and Table 7 contains the results using Amihud's illiquidity measure. We take the log of both of these measures so that the effects of the explanatory variables can be interpreted in percentage terms. Because these two measures are always positive by construction, the log transformation does not change the sample size. ${ }^{17}$ Table 8 contains the decomposition of price-impact into its permanent (information cost) and temporary (order-processing cost) components. Neither of these measures is constrained to be positive (although most are), so we do not apply the log transformation. We report four

\footnotetext{
${ }^{16}$ See Strahan (2009) and Ivashina and Scharfstein (2009) for broader discussion of these issues.

${ }^{17}$ The log transformation also mitigates the influence of outliers.
} 
specifications for each of the dependent variables - clustering the data by either 2-digit or 3-digit SIC code, and reporting both the random effects GLS estimator and the fixed effects estimator. In all of the models we report robust standard errors clustered by industry groups.

Tables 6 and 7 show unambiguously that liquidity falls more after September 2008 for stocks with high levels of ownership by Lehman's hedge-fund clients. Both the bid-ask spread and the Amihud measure rise more after Lehman's failure for stocks that were held by these hedge funds. The increase in illiquidity is statistically significant across all four specifications using the bid-ask spread, and in the random effects models using the Amihud illiquidity measure. Point estimate are very similar for the random and fixed effects models. If we compare a stock with $5 \%$ of its shares owned by Lehman funds with another having no ownership by these funds, the coefficient implies an increase in the bid-ask spread of about $4.5 \%$ more after the crisis for the stocks with hedge fund ownership, and an increase in the Amihud index of about $4 \%$ more after the crisis. While this magnitude may seem small compared to the overall drop in market liquidity (recall Table 5), it is larger relative to the cross-sectional variation in changes to market liquidity. For example, the standard deviation (across stocks) of the change in the $\log$ of the bid-ask spread was about 0.48 , so our coefficient explains almost $7 \%$ of this variation. $^{18}$

Moreover, the sign of Lehman hedge-fund ownership consistently enters with opposite sign of ownership by other hedge funds and other institutions (and we can reject

\footnotetext{
${ }^{18} \mathrm{We}$ also find that smaller firms experienced greater declines in liquidity than larger ones. This effect is difficult to see in Tables 6 and 7 because we include two highly-correlated size measures. However, if we drop log of market capitalization and load all of the size effects onto the size rank coefficient, we estimate a negative and significant coefficient, as we do if we reverse this experiment and drop size rank.
} 
the hypothesis that the Lehman hedge-fund ownership effect is equal to the effect of other institutional ownership variables at the $5 \%$ level in all four models for Table 6 , and in the random effects models in Table 7). In contrast, we find no statistically significant difference in the effects of non-Lehman hedge fund (Row b in Tables 6 \& 7) ownership relative to ownership by other institutional investors (Row $\mathrm{c}$ in Tables $6 \&$ 7). Our findings thus suggest that institutional ownership overall mitigated the drop in market liquidity that followed Lehman's collapse, which as we have mentioned was followed in quick succession by a series of shocks to the market, including the AIG bailout, runs on money market funds, and dramatic actions taken by the U.S. Treasury, the Federal Reserve and the European Central Bank to try to halt the panic. Thus institutional holdings moderated the adverse consequences of these shocks on market liquidity, but Lehman's hedge-fund clients could not contribute to this moderating effect because their positions were frozen in bankruptcy. ${ }^{19}$

In Table 8, we find that the permanent component of price impact for stocks held by Lehman hedge funds actually declines significantly, relative to stocks held by others (columns 1-4). This suggests that while overall liquidity is dampened because the Lehman funds could not trade after September 15, the information component of trades, which drives the permanent effect of volume on price, is reduced. Other liquidity suppliers - market makers - face an exogenous drop in the likelihood of trading against potentially well-informed hedge funds when Lehman fails, thus lowering the impact of

\footnotetext{
${ }^{19}$ We have also tested whether the Lehman-connected stocks earned abnormal returns. To do so, we create a portfolio that includes all stocks in which the Lehman-connected hedge funds owned more than $5 \%$. From these stocks, we compute the daily return (from CRSP), weighted by market values, during the pre and post-Lehman bankruptcy period. The estimate of alpha is not statistically significant in the postLehman sample (September 15 - December 30, 2008) in either model; nor is alpha significant in the preLehman sample.
} 
volume on price for these stocks. We find this effect across all four specifications. The presence of hedge funds in the market raises the probability of private information and thus increases the adverse selection component of trading costs.

The last four columns in Table 8 suggest that the temporary component of priceimpact - that part of price impact related to order-processing costs - increases more for stocks held by Lehman funds. The coefficient is not statistically significantly different from zero, but it is significantly different from the coefficient on other hedge funds (i.e. hedge funds not affected by Lehman). In addition, while the temporary component of price impact in the post-crisis period is significantly lower among stocks owned by nonLehman institutions, this relation is even stronger among the sub-category of nonLehman hedge funds. Thus, while hedge funds supply liquidity overall, their ability to do so is affected by shocks to funding from their prime broker.

In our last set of tests, we re-estimate the models for stocks that had abovemedian vs. below-median levels of liquidity in the pre-crisis period. Brunnermeier and Pedersen (2007) suggest that links from funding liquidity to market liquidity ought to be greatest for relatively illiquid assets, so we ought to observe a greater impact on market liquidity of the Lehman bankruptcy for those stocks that were more illiquid prior to the shock. This is indeed what we find (Table 9). For stocks with below-median initial liquidity, we estimate large and significant effects of the Lehman bankruptcy; for the above-median liquidity stocks, however, the effects are smaller and not statistically significant for most liquidity measures. In terms of magnitudes, an increase in ownership from zero to $5 \%$ by the Lehman-connected funds would come with a $5 \%$ increase in the bid-ask spread and a 10\% increase in the Amihud illiquidity index. 


\section{Conclusions}

Shocks to fundamentals that reduce financial institutions' wealth (capital) may potentially set off a downward spiral in both asset prices and market liquidity as constraints on traders tighten (Brunnermeier and Pedersen, 2007). This idea helps explain why market liquidity in US equities dried up spectacularly after the failure of Lehman Brothers, followed in close succession by a cascade of shocks into both credit markets and stock markets across the world. Tracing a causal connection from the funding liquidity of traders to the market liquidity of their positions is difficult, however, for at least two reasons. First, since illiquid assets make bad collateral, there is a twoway feedback between market liquidity of positions and funding liquidity of traders. Second, traders have incentives to tilt their positions toward less liquid markets (to profit from temporary deviations between prices and fundamentals) and to move in and out of positions as liquidity changes (as was done by LTCM).

In this paper, we avoid these endogeneity problems and offer direct evidence that declines in funding liquidity caused declines in market liquidity. We exploit the Lehman bankruptcy as a plausibly exogenous negative shock to funding liquidity. Hedge funds that used Lehman as their prime broker faced a sudden loss of funding liquidity. Some funds had all of their positions frozen after the bankruptcy filing. We show first that hedge funds using Lehman as prime broker were more than twice as likely to fail after September as other funds, conditional on their past returns and investment flows. This result supports our key identification assumption that Lehman's demise harmed its hedge fund clients. Second, we show that the market liquidity of stocks held by Lehman's 
hedge-fund clients fell more during the crisis than otherwise similar stocks not held by these funds. Ownership by institutional investors, both hedge funds and others, seemed to mitigate the decline in liquidity. Our finding suggests that the demise of Lehman prevented some hedge-fund investors from playing this stabilizing role. 


\section{REFERENCES}

Aiken, James and Monmohan Singh, 2009, "Deleveraging after Lehman: Evidence from Reduced Rehypothecation," http://www.imf.org/external/pubs/ft/wp/2009/wp0942.pdf.

Acharya, Viral and Lasse Pedersen, 2005, “Asset Pricing with Liquidity Risk," Journal of Financial Economics 77, 375-410.

Agarwal, Vikas, William H. Fung, Yee Cheng Loon, and Narayan Naik, 2007. Liquidity Provision in the Convertible Bond Market: Analysis of Convertible Bond Hedge Funds," CFR Working Paper No. 04-03.

Amihud, Yakov, 2002, "Illiquidity and Stock Returns: Cross Section and Time Series Effects," Journal of Financial Markets 5, 31-56

Amihud, Yakov and H. Mendelson, 1986, "Asset Pricing and the Bid-Ask Spread," Journal of Financial Economics 17, 223-49.

Aragon, George O., 2007, "Share Restrictions and Asset Pricing: Evidence from the Hedge Fund Industry," Journal of Financial Economics 83, 33-58.

Aragon, George O. and J. Spencer Martin, 2009, "A Unique View of Hedge Fund Derivatives Usage: Safeguard or Speculation?," http://papers.ssrn.com/sol3/papers.cfm?abstract id $=1108795$.

Brennan, Michael J. and A. Subramanyam, 1996, "Market Microstructure and Asset Pricing: On the Compensation for Illiquidity in Stock Returns," Journal of Financial Economics 41, 441-64.

Brunnermeier, Markus and Stefan Nagel, 2004, "Hedge Funds and the Technology Bubble," Journal of Finance 59, 2013-2040.

Brunnermeier, Markus and Lasse Pedersen, 2009, "Market Liquidity and Funding Liquidity," Review of Financial Studies 22, 2201-2238.

Cahill, Tom. Lehman Hedge-Fund Clients Left Cold as Assets Frozen. Bloomberg.com. October 1, 2008. http://www.bloomberg.com/apps/news?pid=20601087\&sid=adjHB.7sfLDA\&refer=home

Choi, Darwin, Mila Getmansky, and Heather Tookes, 2009. "Convertible Bond Arbitrageurs as Suppliers of Capital," Journal of Financial Economics, forthcoming.

Chordia, Tarun, Richard Roll and A. Subramanyam, 2001, "Market Liquidity and Trading Activity," Journal of Finance 45, 501-30. 
Ivashina, Victoria and David Scharfstein, 2009, "Bank Lending during the Financial Crisis of 2008," http://papers.ssrn.com/sol3/papers.cfm?abstract_id=1297337.

Getmansky, Mila, Andrew Lo and Shauna Mei, 2004, "Sifting Through the Wreckage: Lessons from Recent Hedge Fund Liquidations," Journal of Investment Management 2(4), 6-38.

Glosten, Lawrence R. and Lawrence E. Harris, 1988, "Estimating the Components of the Bid/Ask Spread," Journal of Financial Economics 21, 123-42.

Griffin, John and Xu, 2009, "How Smart Are the Smart Guys? A Unique View From," Review of Financial Studies, forthcoming.

Lee, Charles and Mark J. Ready, 1991, "Inferring Trade Direction from Intraday Data," Journal of Finance 46, 733-46.

Liu, Xiuwen, and Antonio S. Mello, 2009. "The Capital Structure of Financial Institutions and Liquidity Crises," http://papers.ssrn.com/sol3/papers.cfm?abstract id=1343617.

Lo, Andrew W., 2008, Testimony before the U.S. House of Representatives, November $13,2008$.

Pastor, Lubos and Robert Stambaugh, 2003, "Liquidity Risk and Expected Stock Returns," Journal of Political Economy 111, 642-85.

Sadka, Ronnie, 2006, "Momentum and the Post Earnings Announcment Drift: The Role of Liquiidty Risk," Journal of Financial Economics 80, 309-49.

Strahan, Philip E., 2009, "Liquidity Production in Twenty-First Century Banks," forthcoming in the Oxford Handbook of Banking, edited by Allen Berger and John Wilson, Oxford University Press. 


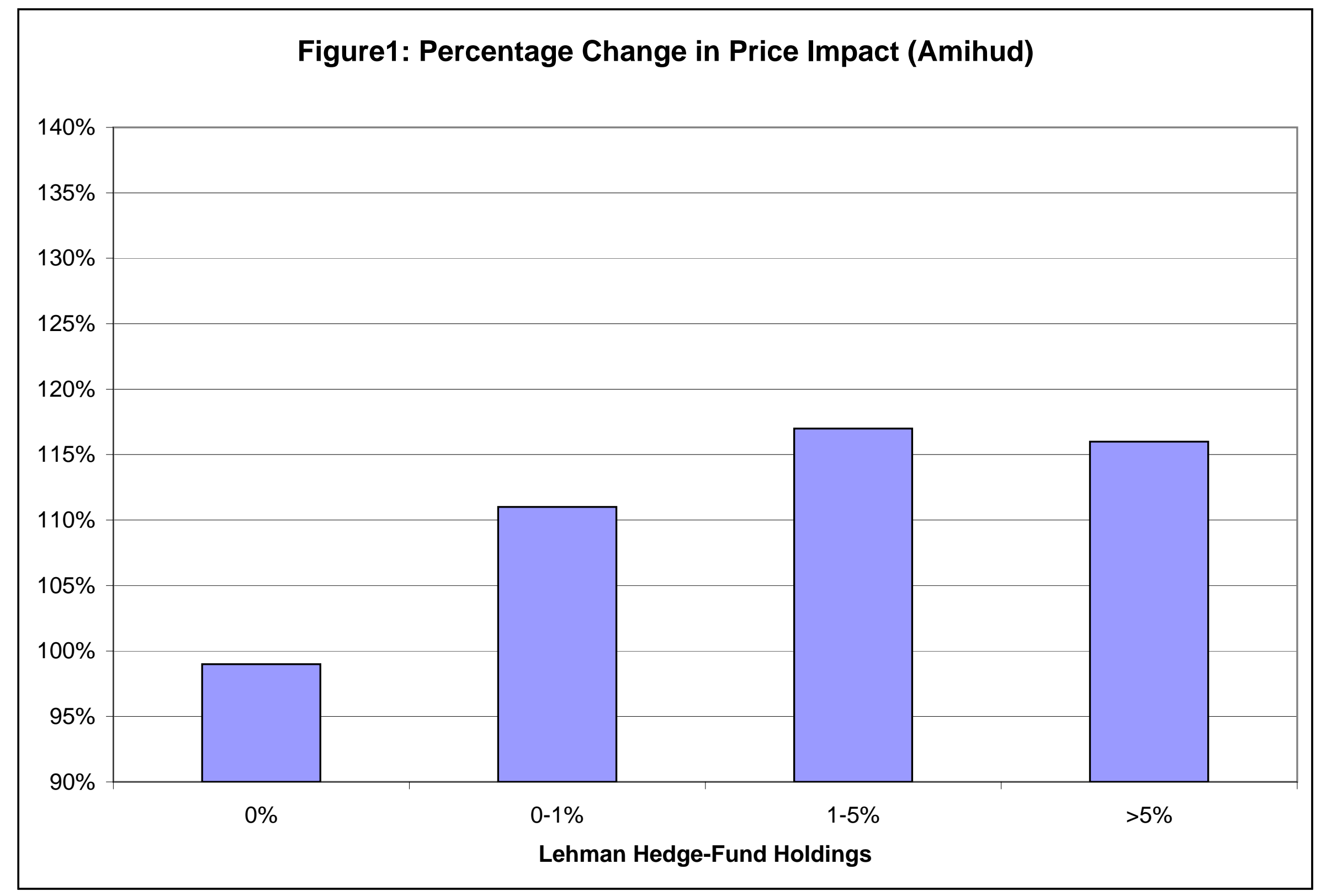




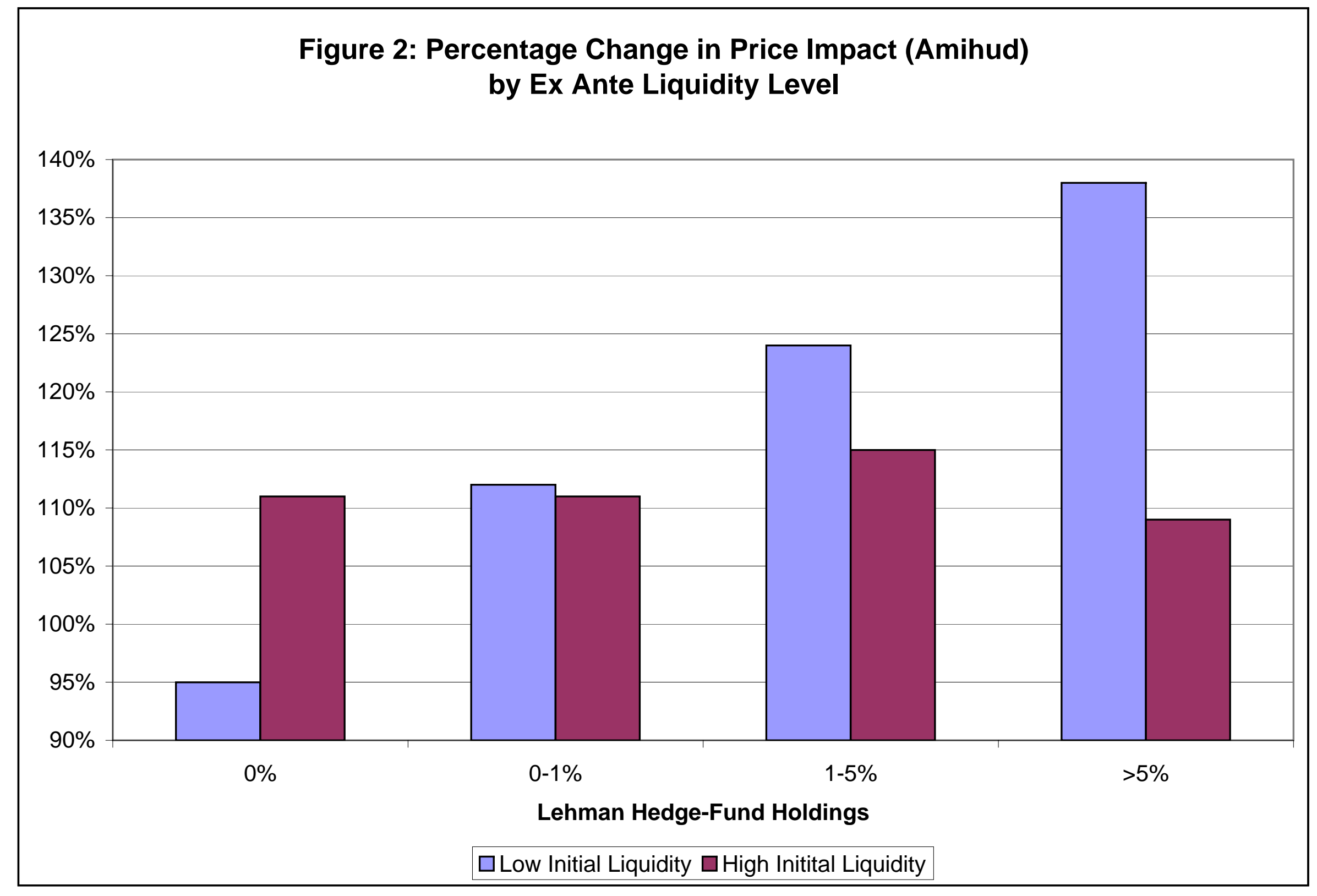




\section{Table 1}

\section{Top Ten Hedge Fund Prime Brokers by Market Share}

This table lists the 10 largest prime brokers in each of the six years of available versions of the TASS database. Market share is computed for each version of the database as the proportion of funds affiliated with a given prime brokerage. The reported values are market share averages across versions by year.

\begin{tabular}{|c|c|c|c|c|c|}
\hline \multicolumn{2}{|r|}{2002} & \multicolumn{2}{|r|}{2003} & \multicolumn{2}{|r|}{$\underline{2005}$} \\
\hline $18.16 \%$ & Bear Stearns & $18.05 \%$ & Bear Stearns & $19.41 \%$ & Morgan Stanley \\
\hline $16.24 \%$ & Morgan Stanley & $16.43 \%$ & Morgan Stanley & $18.38 \%$ & Goldman Sachs \\
\hline $13.65 \%$ & Goldman Sachs & $14.47 \%$ & Goldman Sachs & $13.98 \%$ & Bear Stearns \\
\hline $4.30 \%$ & Bank of America & $5.81 \%$ & ABN AMRO & $8.51 \%$ & UBS \\
\hline $3.67 \%$ & ABN AMRO & $5.14 \%$ & Bank of America & $6.03 \%$ & Bank of America \\
\hline $3.65 \%$ & Morgan Stanley Dean Witter & $2.91 \%$ & Merrill Lynch & $3.33 \%$ & Lehman Brothers \\
\hline $3.40 \%$ & Merrill Lynch & $2.64 \%$ & Morgan Stanley Dean Witter & $3.25 \%$ & Citigroup \\
\hline $2.77 \%$ & Man Group & $2.50 \%$ & Man Group & $3.12 \%$ & Credit Suisse First Boston \\
\hline $2.23 \%$ & ING Group & $1.96 \%$ & Salomon Smith Barney & $2.69 \%$ & Deutsche Bank \\
\hline $1.85 \%$ & Salomon Smith Barney & $1.62 \%$ & Credit Suisse First Boston & $2.39 \%$ & Man Group \\
\hline & $\underline{2006}$ & & $\underline{2007}$ & & $\underline{2008}$ \\
\hline $19.67 \%$ & Morgan Stanley & $20.67 \%$ & Morgan Stanley & $20.60 \%$ & Morgan Stanley \\
\hline $18.24 \%$ & Goldman Sachs & $17.21 \%$ & Goldman Sachs & $16.64 \%$ & Goldman Sachs \\
\hline $13.21 \%$ & Bear Stearns & $12.00 \%$ & Bear Stearns & $9.13 \%$ & Bear Stearns \\
\hline $8.61 \%$ & UBS & $8.24 \%$ & UBS & $8.58 \%$ & UBS \\
\hline $5.53 \%$ & Bank of America & $4.53 \%$ & Bank of America & $4.14 \%$ & Deutsche Bank \\
\hline $3.88 \%$ & Citigroup & $4.15 \%$ & Citigroup & $3.90 \%$ & Citigroup \\
\hline $3.55 \%$ & Lehman Brothers & $3.68 \%$ & Deutsche Bank & $3.46 \%$ & Merrill Lynch \\
\hline $3.29 \%$ & Credit Suisse First Boston & $3.58 \%$ & Credit Suisse First Boston & $3.37 \%$ & Credit Suisse First Boston \\
\hline $2.57 \%$ & Deutsche Bank & $3.31 \%$ & Lehman Brothers & $3.04 \%$ & Bank of America \\
\hline $2.36 \%$ & Man Group & $2.96 \%$ & Merrill Lynch & $2.36 \%$ & Lehman Brothers \\
\hline
\end{tabular}




\section{Table 2}

Summary of Hedge Fund Affiliations with Prime Broker

This table summarizes variables related to hedge funds' affiliations with prime brokerages as reported in 102 versions of the TASS database over 2002-2009. FundYear observations counts the number of unique fund-year observations.

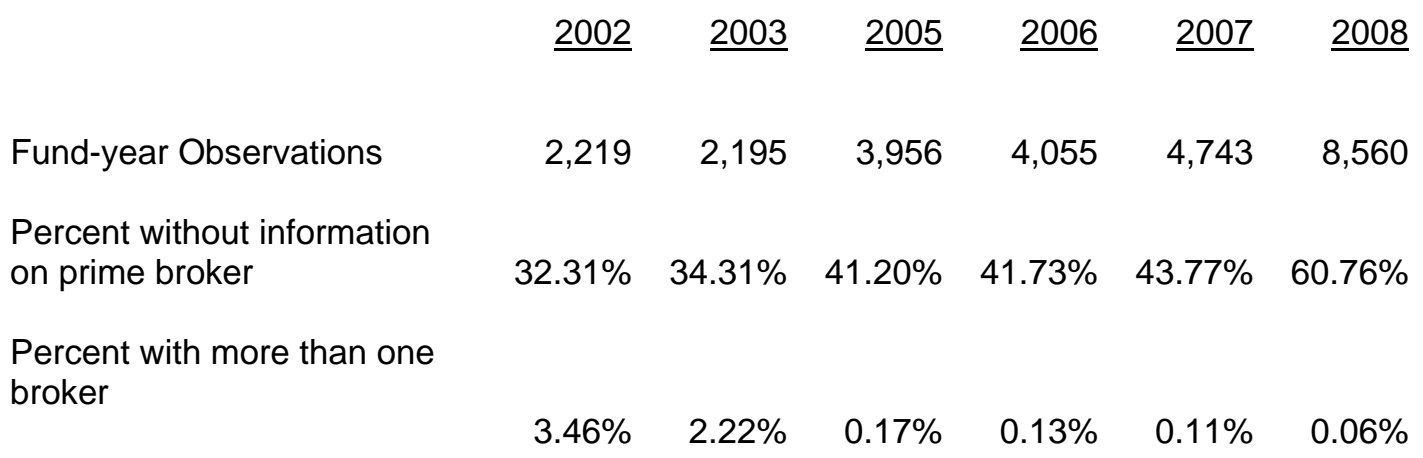




\section{Table 3}

\section{Summary Statistics of Lehman and Non-Lehman Affiliated Funds in 2008}

The table summarizes performance and characteristic variables for the sample of funds reporting to TASS in 2008. Variables are summarized for subgroups depending on whether the fund lists Lehman Brothers as a prime broker in the last report to TASS prior to September, 2008. We drop funds that do not report any prime brokerage affiliate. Liquidated in 2008 indicates whether the fund's final non-missing reported return to TASS occurs in 2008. Raw Return is the cumulative monthly return measured over 2007. All funds are required to have a full twelve monthly return observations to be included in the raw return calculation. Net Investor Flow is the percentage net asset flow to the fund in 2007. Net Assets is the estimated asset value reported to TASS at the end of 2007. Fund Age is the number of days between the inception date of the fund and December 31, 2007. Notice Period is the number of days notice investors must provide to redeem their shares in the fund. Lockup is an indicator variable that equals one if the fund has a positive lockup period. Restrictive Fund indicates whether the fund has a lockup and at least a 30-day notice period, or allows redemptions no more than twice a year. Fund style categories are indicator variables corresponding to the reported fund style.

\begin{tabular}{|c|c|c|c|c|c|c|}
\hline \multirow[t]{2}{*}{$\underline{\text { Variable }}$} & \multicolumn{2}{|c|}{ Lehman Funds } & \multicolumn{2}{|c|}{ Non-Lehman Funds } & \multicolumn{2}{|c|}{ Difference in Means } \\
\hline & $\underline{N}$ & Mean & $\underline{N}$ & Mean & $\underline{\text { Diff }}$ & $\underline{t(\text { Diff })}$ \\
\hline Liquidated in 2008 Dummy & $\overline{77}$ & $\overline{45.45 \%}$ & $2 \overline{66} 6$ & $31.73 \%$ & $13 . \overline{72} \%$ & $2.54^{\star \star}$ \\
\hline Monthly Observations in 2008 & 77 & 9.56 & 2663 & 10.42 & -0.86 & $2.48^{\star *}$ \\
\hline \multicolumn{7}{|c|}{ Lagged Variables Measured in 2007} \\
\hline Raw Return & 76 & $5.61 \%$ & 2626 & $12.35 \%$ & $-6.74 \%$ & $2.79 * \star$ \\
\hline Net Investor Flows & 41 & $21.62 \%$ & 1415 & $38.81 \%$ & $-17.18 \%$ & 0.86 \\
\hline Logarithm of Net Assets & 46 & 17.50 & 1478 & 18.02 & -0.53 & $1.98^{*}$ \\
\hline \multicolumn{7}{|l|}{ Share Restrictions on Investors } \\
\hline Logarithm of Notice Period & 74 & 3.04 & 2645 & 3.28 & -0.24 & $1.96^{\star}$ \\
\hline Lockup Dummy & 74 & 0.37 & 2645 & 0.71 & -0.34 & $2.49 * *$ \\
\hline \multicolumn{7}{|l|}{ Fund Style Categories } \\
\hline Convertible Arbitrage? & 74 & $8.11 \%$ & 2645 & $2.57 \%$ & $5.54 \%$ & $2.89 * \star$ \\
\hline Dedicated Short Bias? & 74 & $0.00 \%$ & 2645 & $0.57 \%$ & $-0.57 \%$ & 0.65 \\
\hline Emerging Markets? & 74 & $0.00 \%$ & 2645 & $6.20 \%$ & $-6.20 \%$ & $2.21^{*}$ \\
\hline Equity Market Neutral? & 74 & $6.76 \%$ & 2645 & $6.50 \%$ & $0.25 \%$ & 0.09 \\
\hline Event Driven? & 74 & $6.76 \%$ & 2645 & $8.13 \%$ & $-1.37 \%$ & 0.43 \\
\hline Fixed Income Arbitrage? & 74 & $13.51 \%$ & 2645 & $4.57 \%$ & $8.94 \%$ & $3.55^{\star \star}$ \\
\hline Fund of Funds? & 74 & $1.35 \%$ & 2645 & $9.00 \%$ & $-7.65 \%$ & $2.29^{\star}$ \\
\hline Global Macro? & 74 & $10.81 \%$ & 2645 & $3.93 \%$ & $6.88 \%$ & $2.94^{\star \star}$ \\
\hline Long/Short Equity Hedge? & 74 & $35.14 \%$ & 2645 & $45.10 \%$ & $-9.97 \%$ & 1.70 \\
\hline Managed Futures? & 74 & $4.05 \%$ & 2645 & $6.65 \%$ & $-2.60 \%$ & 0.89 \\
\hline Multi-Strategy? & 74 & $13.51 \%$ & 2645 & $6.73 \%$ & $6.78 \%$ & $2.27^{\star}$ \\
\hline Other? & 74 & $0.00 \%$ & 2645 & $0.00 \%$ & $0.00 \%$ & \\
\hline Undefined? & 74 & $0.00 \%$ & 2645 & $0.04 \%$ & $-0.04 \%$ & 0.17 \\
\hline
\end{tabular}




\section{Table 4: Hazard Model predicting exit of hedge funds from the market}

This table reports a hazard model that relates the survival rate of each hedge fund to its performance and its use of Lehman Brothers as prime broker. The sample includes all hedge funds in existence as of 2002, as well as all hedge funds formed after 2002 (based on TASS). Hedge funds are assumed to have failed if they drop out of the TASS database. A coefficient greater than one indicates an increasing relationship between the co-variate and the survival probability; a coefficient below one indicates the opposite. We report a Z-statistics that are asypmptotically normally distributed under the null that the coefficient equals one.

\begin{tabular}{|c|c|c|c|c|c|c|}
\hline & $\underline{1}$ & $\underline{2}$ & $\underline{3}$ & $\underline{4}$ & $\underline{5}$ & $\underline{6}$ \\
\hline \multirow[t]{2}{*}{2008 Dummy } & 2.175 & 1.5406 & 1.7103 & 1.7386 & 1.7433 & 1.7414 \\
\hline & $19.17 * *$ & $7.66 * *$ & $7.18 * *$ & $7.15^{* *}$ & $7.18 * *$ & $7.18^{* *}$ \\
\hline \multirow[t]{2}{*}{ Lehman Fund Dummy } & 0.8025 & 0.7555 & 0.7385 & 0.7164 & 0.7173 & 0.6953 \\
\hline & 1.31 & $1.65+$ & 1.32 & 1.35 & 1.35 & 1.45 \\
\hline \multirow[t]{2}{*}{2008 Dummy*Lehman Fund Dummy } & 1.9794 & 2.089 & 2.3139 & 2.3112 & 2.3117 & 2.2428 \\
\hline & $2.91 * *$ & $3.13^{* *}$ & $2.56^{*}$ & $2.48 *$ & $2.48 *$ & $2.38 *$ \\
\hline \multirow[t]{2}{*}{ Raw Fund Return } & - & 0.7308 & 0.7748 & 0.8056 & 0.806 & 0.8018 \\
\hline & - & $16.20 * *$ & $9.83 * *$ & $8.11^{* *}$ & $8.10^{* *}$ & $8.24 * *$ \\
\hline \multirow[t]{2}{*}{ Percentage Net Fund Flow } & - & - & 0.5566 & 0.6701 & 0.6689 & 0.6685 \\
\hline & - & - & $7.14^{* *}$ & $5.55^{* *}$ & $5.55 * *$ & $5.60 * *$ \\
\hline \multirow[t]{2}{*}{ Ln(Fund Assets) } & - & - & - & 0.7417 & 0.7411 & 0.744 \\
\hline & - & - & - & $9.07 * *$ & $9.01 * *$ & $8.98 * *$ \\
\hline \multirow[t]{2}{*}{ Ln(1+ Lockup Period) } & - & - & - & - & 1.0286 & 1.0304 \\
\hline & - & - & - & - & 1.16 & 1.22 \\
\hline \multirow[t]{2}{*}{ Ln(1+Redemption Notice Period) } & - & - & - & - & 0.987 & 0.991 \\
\hline & - & - & - & - & 0.34 & 0.22 \\
\hline Hedge_Fund Style Fixed Effects? & No & No & No & No & No & Yes \\
\hline $\mathrm{N}$ & 13,981 & 13,680 & 9,425 & 8,977 & 8,977 & 8,977 \\
\hline
\end{tabular}

Robust z statistics in parentheses

+ significant at $10 \%$; * significant at $5 \%$; * significant at $1 \%$ 


\section{Table 5: Distribution of liquidity measures, before and after Lehman Brother's Bankruptcy}

This table describes the distribution of four liquidity measures for the 3-months before and the 3-months after Lehman Brother's bankruptcy filing on September 15, 2008. The bid-ask spread is the dollar difference between the bid and the ask, divided by the midpoint of the spread. Overall price impact equals the average absolute daily price change divided by dollar volume. The permanent component of price impact equals the sensitivity of price changes to unexpected volume, and the temporary component of price impact equals the average increase in prices for small trades (Sadka, 2006). See text for a full descption of these last two liquidity measures.

\section{Panel A: Distribution of Liquidity Measures}

\begin{tabular}{|c|c|c|c|c|c|c|}
\hline & \multicolumn{3}{|c|}{ Pre-Crisis } & \multicolumn{3}{|c|}{ Post-Crisis } \\
\hline & $\begin{array}{c}\text { 25th } \\
\text { percentile }\end{array}$ & Median & 75th percentile & $\begin{array}{c}\text { 25th } \\
\text { percentile }\end{array}$ & Median & 75th percentile \\
\hline Overall price impact (Amihud Illiquidity Measure) & $0.27 \%$ & $2.55 \%$ & $38.42 \%$ & $0.71 \%$ & $7.66 \%$ & $98.85 \%$ \\
\hline Bid-Ask Spread (NYSE only) & $0.11 \%$ & $0.18 \%$ & $0.32 \%$ & $0.26 \%$ & $0.44 \%$ & $0.83 \%$ \\
\hline Permanent-variable (information) price impact (NYSE only) & 0.46 & 2.13 & 4.59 & -0.06 & 2.53 & 5.56 \\
\hline Temporary-fixed (non information) price impact (NYSE only) & 0.012 & 0.021 & 0.040 & 0.015 & 0.025 & 0.051 \\
\hline Share held by Lehman Hedge Funds (June, 2008) & $0.00 \%$ & $0.00 \%$ & $0.25 \%$ & & & \\
\hline Share held by Other Hedge Funds (June, 2008) & $2.16 \%$ & $11.56 \%$ & $23.60 \%$ & & & \\
\hline Share Held By Other Institutions (June, 2008) & $7.31 \%$ & $25.93 \%$ & $51.45 \%$ & & & \\
\hline Number of stocks with more than $5 \%$ ownership by Lehman Funds & & 237 & & & & \\
\hline
\end{tabular}




\section{Table 6: Regression of the Bid-Ask Spread on Lehman-connected Hedge Fund Holdings}

This table reports cross-sectional regressions of the log average effective bid-ask spread ((ask-bid) / mid-point) during the three-months following the Lehman bankruptcy on the log spread before the crisis, market capitalization, the fraction of the stock held by hedge funds that used Lehman as their prime broker, and the fraction held by all other institutional investors. We include industry effects in all models, and standard errors assume clustering at the industry level.

Pre-Crisis Log Spread

Log(Market Capitalization)

Market Capitalization Rank

NASDAQ Stock Dummy

(a) Share Held By Lehman Hedge Funds

(b) Share Held By Other Hedge Funds

(c) Share Held By Other Institutions

P-value for F-Test that: $(\mathrm{a})=(\mathrm{b})$

P-value for F-Test that: $(\mathrm{a})=(\mathrm{c})$

P-value for F-Test that: (b) $=(c)$

Observations

R-squared (within industry)

Level of Industry Clustering

\begin{tabular}{cccc}
\multicolumn{2}{c}{ Random Industry Effects } & \multicolumn{2}{c}{ Fixed Industry Effects } \\
\hline 0.8058 & 0.8097 & 0.8046 & 0.8024 \\
$83.08^{* *}$ & $80.94^{* *}$ & $25.98^{* *}$ & $32.39^{* *}$ \\
0.1453 & 0.1493 & 0.1448 & 0.1487 \\
$9.56^{* *}$ & $9.77^{* *}$ & $3.78^{* *}$ & $3.44^{* *}$ \\
-1.6426 & -1.6405 & -1.6505 & -1.6878 \\
$14.74^{* *}$ & $14.61^{* *}$ & $5.86^{* *}$ & $5.73^{* *}$ \\
-0.0452 & -0.0479 & -0.0413 & -0.0271 \\
$2.99 * *$ & $3.13^{* *}$ & $3.05^{* *}$ & 1.53 \\
0.9191 & 0.9235 & 0.8843 & 0.8947 \\
$3.13^{* *}$ & $3.14^{* *}$ & $2.38^{*}$ & $3.27 * *$ \\
-0.1398 & -0.15 & -0.1373 & -0.1372 \\
$2.04 *$ & $2.18^{*}$ & 1.27 & 1.19 \\
-0.209 & -0.2246 & -0.2 & -0.1983 \\
$5.18^{* *}$ & $5.53^{* *}$ & $4.75^{* *}$ & $3.23^{* *}$ \\
& & & \\
\hline 0.001 & 0.000 & 0.015 & 0.002 \\
0.000 & 0.000 & 0.004 & 0.000 \\
0.465 & 0.432 & 0.599 & 0.687 \\
5,741 & 5,741 & 5,741 & 5,741 \\
0.88 & 0.88 & 0.88 & 0.88 \\
$2-$ Digit & $3-$ Digit & $2-$ Digit & $3-$ Digit \\
\hline & & &
\end{tabular}

+ significant at $10 \%$; ${ }^{*}$ significant at $5 \%$; ${ }^{* *}$ significant at $1 \%$ 


\section{Table 7: Regression of Overall Price Impact (Amihud Measure) on Lehman-connected Hedge Fund Holdings}

This table reports cross-sectional regressions of the log the Amihud measure of price impact (absolute price change per unit of dollar volume) during the three-months following the Lehman bankruptcy on the log of the Amihud measure before the crisis, market capitalization, and the fraction of the stock held by hedge funds that used Lehman as their prime broker. We include industry effects in all models, and standard errors assume clustering at the industry level.

Pre-Crisis Log Amihud Liquidity Measure

Log(Market Capitalization)

Market Capitalization Rank

NASDAQ Stock Dummy

(a) Share Held By Lehman Hedge Funds

(b) Share Held By Other Hedge Funds

(c) Share Held By Other Institutions

P-value for F-Test that: $(\mathrm{a})=(\mathrm{b})$

P-value for F-Test that: $(\mathrm{a})=(\mathrm{c})$

P-value for F-Test that: (b) $=(\mathrm{c})$

Observations

R-squared (within industry)

Level of Industry Clustering

\begin{tabular}{cccc}
\multicolumn{2}{c}{ Random Industry Effects } & \multicolumn{2}{c}{ Fixed Industry Effects } \\
\hline 0.8632 & 0.854 & 0.8644 & 0.8576 \\
$77.10^{* *}$ & $73.96^{* *}$ & $16.66^{* *}$ & $16.70^{* *}$ \\
-0.0806 & -0.0827 & -0.0761 & -0.0727 \\
$3.17^{* *}$ & $3.24^{* *}$ & $2.62^{*}$ & $2.61^{* *}$ \\
-0.6385 & -0.7272 & -0.6741 & -0.7688 \\
$3.53^{* *}$ & $3.98^{* *}$ & 0.9 & 0.95 \\
0.1753 & 0.1816 & 0.1692 & 0.1865 \\
$6.59^{* *}$ & $6.71^{* *}$ & $6.09^{* *}$ & $5.94^{* *}$ \\
0.9338 & 0.7486 & 0.7679 & 0.5588 \\
$1.97 *$ & 1.61 & 1.13 & 1.01 \\
-0.3358 & -0.3937 & -0.3374 & -0.3775 \\
$2.88^{* *}$ & $3.35^{* *}$ & $2.55^{*}$ & $2.58^{*}$ \\
-0.1898 & -0.2324 & -0.1567 & -0.2059 \\
$2.95^{* *}$ & $3.58^{* *}$ & $2.48^{*}$ & $2.81^{* *}$ \\
& & & \\
\hline 0.010 & 0.019 & 0.111 & 0.096 \\
0.019 & 0.038 & 0.179 & 0.166 \\
0.357 & 0.308 & 0.232 & 0.280 \\
5,767 & 5,767 & 5,767 & 5,767 \\
0.94 & 0.94 & 0.94 & 0.94 \\
$2-D i g i t$ & $3-D i g i t$ & $2-D i g i t$ & $3-D i g i t$ \\
\hline & & &
\end{tabular}

+ significant at 10\%; * significant at 5\%; ** significant at $1 \%$ 


\section{Table 8: Decomposing the Regression of Overall Price Impact on Lehman-connected Hedge Fund Holdings}

This table reports cross-sectional regressions of the variabe and fixed components of price impact during the three-months following the Lehman bankruptcy on the log spread before the crisis, market capitalization, and the fraction of the stock held by hedge funds that used Lehman as their prime broker. The sample include just NYSE stocks. We include industry effects in all models, and standard errors assume clustering at the industry level.

Pre-Crisis Price Impact

Permanent-variable (information) price impact

Temporary-fixed (non information) price impact

\begin{tabular}{|c|c|c|c|c|c|c|c|}
\hline \multicolumn{2}{|c|}{ Random Industry Effects } & \multicolumn{2}{|c|}{ Fixed Industry Effects } & \multicolumn{2}{|c|}{ Random Industry Effects } & \multicolumn{2}{|c|}{ Fixed Industry Effects } \\
\hline 0.25 & 0.2518 & 0.2395 & 0.2365 & 0.7943 & 0.7943 & 0.7845 & 0.7847 \\
\hline $6.30 * *$ & $6.36 * *$ & $8.19 * *$ & $6.40 * *$ & $12.43^{* *}$ & $12.43^{* *}$ & $10.43^{* *}$ & $11.49 * *$ \\
\hline-0.2627 & -0.2659 & -0.2437 & -0.137 & 0.003 & 0.003 & 0.0031 & 0.0024 \\
\hline 1.59 & 1.6 & $2.20 *$ & 0.98 & $2.96^{* *}$ & $2.96 * *$ & $3.97 * *$ & $2.35^{*}$ \\
\hline-9.2459 & -9.0909 & -9.4182 & -10.0648 & -0.0686 & -0.0686 & -0.0659 & -0.0589 \\
\hline $4.71^{* *}$ & $4.59 * *$ & $8.74 * *$ & $6.39 * *$ & $5.07 * *$ & $5.07 * *$ & $6.89 * *$ & $5.64 * *$ \\
\hline-10.5064 & -10.284 & -10.7415 & -14.5795 & 0.0335 & 0.0335 & 0.0342 & 0.0406 \\
\hline $2.59 * *$ & $2.58 * *$ & $2.66^{* *}$ & $3.34 * *$ & 1.11 & 1.11 & 1.06 & 1.27 \\
\hline 1.3808 & 1.4468 & 1.6935 & -0.3262 & -0.0376 & -0.0376 & -0.0285 & -0.0233 \\
\hline 0.77 & 0.81 & 0.83 & 0.17 & $5.64 * *$ & $5.64 * *$ & $3.26^{* *}$ & $3.46 * *$ \\
\hline-2.5346 & -2.4143 & -2.7377 & -2.0072 & -0.0106 & -0.0106 & -0.0052 & -0.0012 \\
\hline $2.98 * *$ & $2.83 * *$ & $2.09 *$ & $1.92+$ & $2.54^{*}$ & $2.54^{*}$ & 0.99 & 0.27 \\
\hline 0.009 & 0.009 & 0.010 & 0.002 & 0.024 & 0.024 & 0.075 & 0.215 \\
\hline 0.056 & 0.054 & 0.064 & 0.006 & 0.147 & 0.147 & 0.234 & 0.058 \\
\hline 0.117 & 0.121 & 0.140 & 0.497 & 0.007 & 0.007 & 0.015 & 0.021 \\
\hline 2,067 & 2,067 & 2,067 & 2,067 & 2,063 & 2,063 & 2,063 & 2,063 \\
\hline 0.24 & 0.22 & 0.24 & 0.22 & 0.53 & 0.5 & 0.53 & 0.5 \\
\hline 2-Digit & 3-Digit & 2-Digit & 3-Digit & 2-Digit & 3-Digit & 2-Digit & 3-Digit \\
\hline
\end{tabular}

P-value for F-Test that: $(a)=(c)$

P-value for F-Test that: (b) $=(c)$

Observations

R-squared (within industry)

2-Digit

3-Digit

2-Dig

3-Digit

+ significant at $10 \%$; * significant at $5 \%$; ** significant at $1 \%$ 
Table 9: Regression of the Liquidity on Lehman-connected Hedge Fund Holdings, High v. Low Pre-Crisis Liquidity

This table reports cross-sectional regressions of each of the four liquidity measures during the three-months following the Lehman bankruptcy on the log spread before the crisis, market capitalization, and the fraction of the stock held by hedge funds that used Lehman as their prime broker. Each of the regressions is run separately for firms above and below the initial median level of liquidity measured in the pre-crisis months.

\begin{tabular}{|c|c|c|c|c|c|c|c|}
\hline \multicolumn{2}{|c|}{ Log of Spread } & \multicolumn{2}{|c|}{ Log of Amihud Index } & \multicolumn{2}{|c|}{ Permanent-variable } & \multicolumn{2}{|c|}{ Temporary-fixed (non } \\
\hline High & Low & High & Low & High & & High & Low \\
\hline Liquidity $_{0}$ & Liquidity $_{0}$ & Liquidity $_{0}$ & Liquidity $_{0}$ & Liquidity $_{0}$ & ${\text { Low } \text { Liquidity }_{0}}$ & Liquidity $_{0}$ & Liquidity $_{0}$ \\
\hline 0.8047 & 0.7282 & 1.0525 & 0.7687 & 0.0902 & 0.2024 & 0.6027 & 0.7336 \\
\hline $13.23^{* *}$ & $30.54^{* *}$ & $22.88^{* *}$ & $26.38^{* *}$ & 1.06 & $4.19 * *$ & $5.01 * *$ & $9.43 * *$ \\
\hline 0.1071 & 0.0785 & -0.0208 & 0.0723 & -0.34 & -0.3757 & 0.0004 & 0.0054 \\
\hline $3.06 * *$ & $2.25 *$ & 0.59 & 1.45 & 1.54 & 0.54 & 0.77 & 0.95 \\
\hline-1.1376 & -1.375 & 0.4646 & -2.4197 & -6.7184 & -8.7483 & -0.0187 & -0.0846 \\
\hline $7.57 * *$ & $5.34 * *$ & 1.14 & $3.15 * *$ & $2.68 * *$ & $2.02 *$ & $3.07 * *$ & $2.26^{*}$ \\
\hline-0.103 & 0.0542 & 0.0223 & 0.1876 & - & - & - & - \\
\hline $4.90 * *$ & $1.79+$ & 0.5 & $3.29 * *$ & - & - & - & - \\
\hline 0.8211 & 1.0273 & -0.4163 & 1.9126 & -7.5403 & -19.435 & 0.0122 & 0.109 \\
\hline $2.38 *$ & $2.14^{*}$ & 0.72 & $2.52 *$ & $1.70+$ & $3.20 * *$ & 1.16 & $1.66+$ \\
\hline-0.1007 & -0.0628 & 0.1207 & -0.4365 & -0.28 & -1.6518 & -0.0068 & -0.0483 \\
\hline 0.86 & 0.45 & 0.76 & $2.82 * *$ & 0.19 & 0.47 & $3.08 * *$ & $3.18 * *$ \\
\hline-0.2026 & 0.0196 & -0.1098 & -0.2138 & -0.3486 & -4.4454 & -0.0073 & 0.0047 \\
\hline $4.01^{* *}$ & 0.25 & 1.54 & $1.87+$ & 0.4 & $2.47^{*}$ & $4.16^{* *}$ & 0.43 \\
\hline 0.018 & 0.030 & 0.390 & 0.004 & 0.103 & 0.015 & 0.080 & 0.022 \\
\hline 0.003 & 0.035 & 0.599 & 0.006 & 0.118 & 0.025 & 0.086 & 0.131 \\
\hline 0.482 & 0.649 & 0.229 & 0.305 & 0.974 & 0.530 & 0.882 & 0.019 \\
\hline 2,740 & 3,001 & 2,706 & 3,061 & 1,036 & 1,031 & 1,027 & 1,036 \\
\hline 0.45 & 0.75 & 0.89 & 0.83 & 0.14 & 0.17 & 0.15 & 0.41 \\
\hline 3-Digit & 3-Digit & 3-Digit & 3-Digit & 3-Digit & 3-Digit & 3-Digit & 3-Digit \\
\hline
\end{tabular}

P-value for F-Test that: (a)=(b)

P-value for F-Test that: $(a)=(c)$

P-value for F-Test that: (b)=(c)

Observations

R-squared (within industry)

3-Digit

3-Digit

3-Digit 3-Digit

$\frac{\text { Level of Industry Clustering (Fixed Effects) }}{\text { + significant at } 10 \% \text {; }{ }^{*} \text { significant at } 5 \% \text {; }{ }^{*} \text { significant at } 1 \%}$ 